\title{
Exploration of a Submerged Sinkhole Ecosystem in Lake Huron
}

\author{
Bopaiah A. Biddanda, ${ }^{*}$ Dwight F. Coleman, ${ }^{2,6}$ Thomas H. Johengen, ${ }^{3}$ \\ Steven A. Ruberg, ${ }^{4}$ Guy A. Meadows, ${ }^{5}$ Hans W. Van Sumeren, ${ }^{5}$ \\ Richard R. Rediske, ${ }^{1}$ and Scott T. Kendall ${ }^{1}$
}

\begin{abstract}
${ }^{1}$ Annis Water Resources Institute and Lake Michigan Center, Grand Valley State University, 740 W Shoreline Drive, Muskegon, Michigan 49441, USA; ${ }^{2}$ Institute for Exploration, 55 Coogan Blvd., Mystic, Connecticut 06355, USA; ${ }^{3}$ Cooperative Institute for Limnology and Ecosystems Research, University of Michigan, 2205 Commonwealth Blvd., Ann Arbor, Michigan 48105, USA; ${ }^{4} \mathrm{Na-}$ tional Oceanic and Atmospheric Administration, Great Lakes Environmental Research Laboratory, 2205 Commonwealth Blvd., Ann Arbor, Michigan 48105, USA; ${ }^{5}$ Department of Naval Architecture \& Marine Engineering, University of Michigan, 1085 South University Ave, Ann Arbor, Michigan 48109, USA; ${ }^{6}$ Graduate School of Oceanography, University of Rhode Island, South Ferry Road, Narragansett, Rhode Island 02882, USA
\end{abstract}

\begin{abstract}
Dissolution of the Silurian-Devonian aquifer in the Lake Huron Basin has produced several karst formations in the bedrock (sinkholes), through which groundwater emerges onto the lake floor. During September 2003, we explored a recently discovered submerged sinkhole ecosystem $(55 \mathrm{~m} \times$ $40 \mathrm{~m} \times \sim 1 \mathrm{~m}$ ) located at a depth of $93 \mathrm{~m}$ with a remotely operated vehicle (ROV) equipped with a conductivity-temperature-depth (CTD) system, an acoustic navigational system, a video camera, and a water sampling system. In addition to two morphotypes of benthic mats, a 1-2 m thick visibly cloudy near-bottom nepheloid-like layer (sinkhole plume) with a strong hydrogen sulfide odor prevailed just above the seepage area of clear water. Relative to lake water, water samples collected within the sinkhole plume were characterized by slightly higher (by $4^{\circ} \mathrm{C}$ ) temperatures, very high levels of chloride (up to $175 \mathrm{mg} \mathrm{l}^{-1}$ ) and conduc-
\end{abstract}

\section{INTRODUCTION}

"Living creatures and the inanimate worlds they inhabit dance an intimate tango" - American Academy of Microbiology (2001).

Received 20 April 2005; accepted 18 October 2005; published online 10 August 2006.

*Corresponding author; e-mail: biddandb@gvsu.edu tivity $\left(1,700 \mu \mathrm{S} \mathrm{cm}^{-1}\right)$, as well as extremely high concentrations of sulfate $\left(1,400 \mathrm{mg} \mathrm{l}^{-1}\right)$, phosphorus $\left(3 \mathrm{mg} \mathrm{l}^{-1}\right)$ and particulate organic matter (400 $\mathrm{mg} \mathrm{C} \mathrm{l}^{-1}$ ). Compared to background lake water, sinkhole plume water was characterized by approximately twofold lower C:N ratios and tenfold higher levels of dissolved organic carbon, bacterial biomass as well as heterotrophic bacterial production. Significant uptake of ${ }^{14} \mathrm{C}$-bicarbonate in dark incubations provided preliminary evidence for occurrence of chemosynthesis, possibly mediated by specialized Bacteria and Archea present in this submerged sinkhole ecosystem in the Laurentian Great Lakes.

Key words: Laurentian Great Lakes Basin; submerged sinkholes; remotely operated vehicle; groundwater seep; nutrients; heterotrophic microbes; chemosynthesis; Lake Huron. 


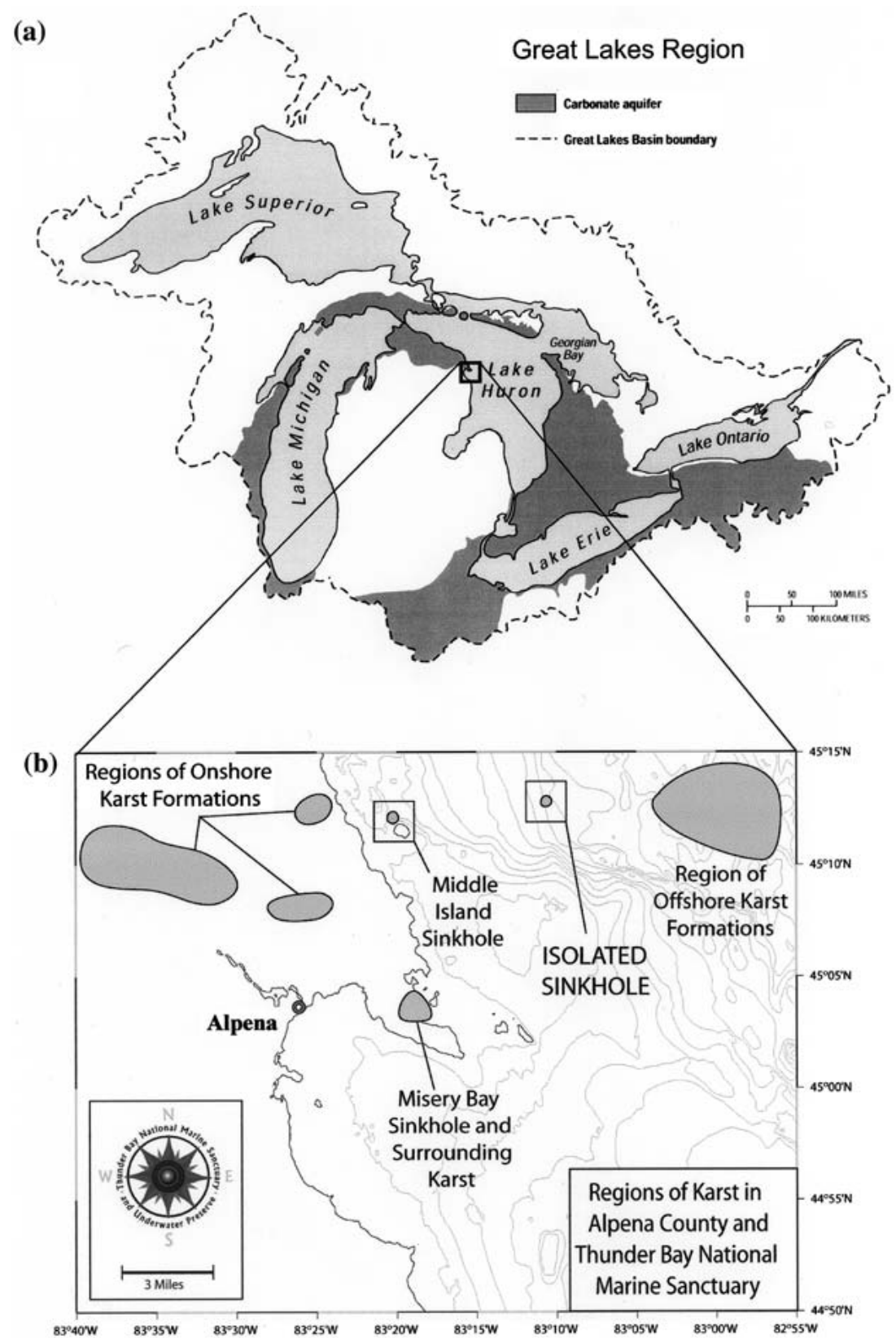

Figure 1. Map of the North American Laurentian Great Lakes Basin showing regions of Devonian-Silurian aquifers potentially having karst formations (a), and regions of aboveground karst formations in the Alpena County, MI and submerged sinkholes (including the study site-Isolated Sinkhole) in the Thunder Bay National Marine Sanctuary, Lake Huron (b). a has been modified from Grannemann and others 2000. b has been modified from coleman 2003. others 2000). These bedrock aquifers were laid down when the shallow seas still spread widely over the continental areas approximately 350-430 million years ago. The Silurian-Devonian aquifer consists of a carbonate-limestone, shale and sandstone matrix and has fresh and saline water, which can contain varying amounts of sulfates, chlorides, fluorides and iron (Briggs 1970; Kimmel 1983; Catacoscinos and others 2001).

Carbonate karst aquifers occur world wide, and cover about $20 \%$ of the land area in the United States (http://www.karstwaters.org). Dissolution of the Silurian-Devonian carbonate aquifer has produced karst features like sinkholes and caves in the Lake Huron basin (Black 1983; Olcott 1992; Schaetzl and others 2000). Sinkholes around the Alpena, Michigan area are present at several onshore locations as well as some nearshore submerged sinkholes known as El Cajon (Misery Bay) and Middle Island sinkholes (Figure $1 \mathrm{~b}$ ). However, the presence of additional submerged sinkholes in this region has remained a mystery until recent times (Coleman 2002).

Submerged sinkholes were serendipitously discovered during the 2001 expedition for shipwrecks in the Thunder Bay National Marine Sanctuary and Underwater Preserve located 
offshore of Alpena, MI, USA (Coleman 2002). The unusually high conductivity (tenfold higher than ambient lake water) measured over some of these sinkholes suggested active groundwater intrusion at depth. During a 2002 expedition to the Thunder Bay National Marine Sanctuary, groundwater seepage was first observed at the "Isolated Sinkhole" at the depth of $93 \mathrm{~m}$ (Figure lb). Highdefinition video recordings and still images were collected from the Isolated Sinkhole by the Institute for Exploration's (IFE) remotely operated vehicle (ROV) "Little Hercules" on board the $R / V$ Connecticut (University of Connecticut), equipped with dynamic positioning (Coleman 2003). During surveys in 2002 as well as 2003, active groundwater seepage was observed at the Misery Bay, Middle Island and Isolated Sinkholes, whereas several sinkholes with no active seepage activity were observed in the northeast region of the sanctuary.

Very little is known regarding the microbiology and biogeochemistry of ground water seeps in large fresh water lakes of the world (Wetzel 2001). Dense communities of microbes and metazoans are known to colonize both thermal vent and cold seep ecosystems (Van Dover 2000). Microbial dominance of carbon and energy flow is especially pronounced in open and deeper waters, away from the land and the productive surface layers (Biddanda and Benner 1997; Karl 1999; Biddanda and others 2001). Evidence from geothermal vents that occur in oceans as well as lakes (Karl and others 1980; Klump and others 1988; Dymond and others 1989; Crane and others 1991; Van Dover 2000), indicate that communities inhabiting these extreme environments support unique food webs and biogeochemical pathways that are primarily mediated by microorganisms-both heterotrophic and chemosynthetic (Wirsen and others 1993; Sievert and others 1999; Reysenbach and others 2000).

In this report, we discuss the preliminary findings from a multidisciplinary exploratory study of the Isolated Sinkhole ecosystem ( 55-m long and 40-m wide) located approximately 10 miles offshore at a depth of $93 \mathrm{~m}$ in the north central region of the Thunder Bay National Marine Sanctuary, Lake Huron, during September $2003\left(45^{\circ} 10.727^{\prime} \mathrm{N}\right.$, $83^{\circ} 09.201^{\prime} \mathrm{W}$; Figure $\mathrm{lb}$ ).

\section{METHODS}

The present study involved shipboard Conductivity-temperature-depth (CTD) vertical tows to characterize the water column, ROV-based video and CTD measurements to map the sinkhole characteristics, sampling the epilimnion with $\mathrm{Ni}$ skin bottle casts, sampling the near bottom sinkhole plume layer with the ROV and shipboard/ laboratory analyses of biogeochemical parameters and processes.

\section{ROV Observations and Sampling}

During the 2003 expedition, all exploratory and sampling operations were conducted from NOAA's 86-foot $R / V$ Laurentian utilizing the University of Michigan's ROV for Education and Research (M-ROVER). M-ROVER is a Benthos Open Frame Sea Rover (length $1.4 \mathrm{~m} \times$ width $0.8 \mathrm{~m} \times$ height 0.7 m) equipped with a Seabird SBE-19 CTD, side scan sonar, selective sampling gear, and a LinkQuest Tracklink ultra-short baseline (USBL) acoustic positioning system (Figure 2a). Detailed high-resolution mapping of conductivity, temperature and depth over the sinkhole environment was achieved by running multiple transects (radiator grid style) with the ROV positioned at about $1.0 \mathrm{~m}$ above the lake floor (Ruberg and others 2005). Observations of the sinkhole were made on monitors in the shipboard control room using the ROV's onboard color video camera. All video and sonar images were recorded to videotape. Furthermore, we characterized the structure of the entire water column using a vertically towed Seabird CTD equipped with a fluorometer and a PAR light sensor.

Water samples for shipboard and laboratory analyses were collected from select sampling points based on the CTD casts and observations from the M-ROVER. Epilimnetic water samples over the sinkhole were collected at 5 and $25 \mathrm{~m}$ using Tefloncoated Niskin bottles. Water samples from the deep region of the sinkhole were collected using the M-ROVER. Flexible silicone tubing ( 13 mm I.D.) was attached to the M-ROVER's manipulator arm and routed through the SBE 19 conductivity cell and along the tether to a peristaltic pump on the deck of the $R / V$ Laurentian. Using the ROV's articulated arm to position the sampling tube forward, real time, selective sampling was conducted at several locations within and flanking the sinkhole. Actual sample collection at any given site was initiated only after synchronizing conductivity at the inlet (M-ROVER's CTD) with that at the outlet on board the ship using a hand-held YSI model 30 conductivity meter which typically was after pumping for approximately 8 min per sample site at the rate of approximately $41 \mathrm{~min}^{-1}$. All samples were collected in acid-cleaned 1 l polycarbonate bottles without any headspace. 

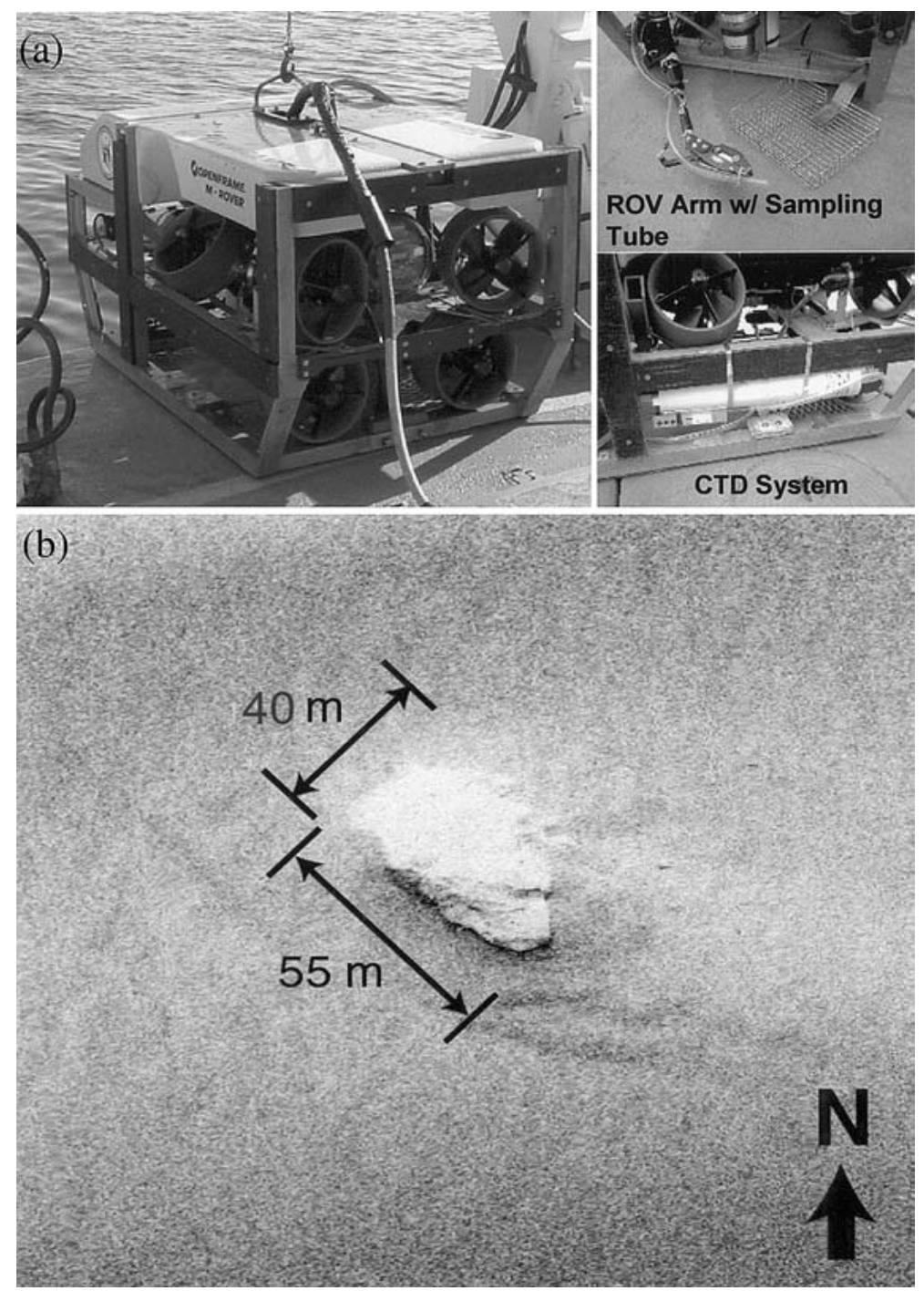

Figure 2. The University of Michigan's Openframe M-ROVER showing rear/side view, location of sampling tube attached to the ROV front arm, and CTD system attached to one side of the ROV frame (a), and side scan sonar image of the Isolated Sinkhole located at 93-m depth having approximate dimensions of $40 \times$ $55 \mathrm{~m}$ (b; modified from Coleman 2003). Note the slight depression of the sinkhole region $(\sim 0.5-2 \mathrm{~m})$ relative to the adjacent lake floor in the sonar image.

\section{Biogeochemical Measurements}

Physical-Chemical Parameters. Analyses for $\mathrm{pH}$ were conducted using a portable Accumet AP63 pH meter. Carbonate alkalinity was determined by acid-titration according to the methods of Wetzel and Likens (2000). DIC was determined from alkalinity using equations of Wetzel and Likens (2000). For total phosphorus (P), $50 \mathrm{ml}$ samples were collected in an acid-cleaned $70 \mathrm{ml}$ Pyrex testtube and refrigerated until analysis. Total $\mathrm{P}$ was determined using standard colorimetric procedures on an auto analyzer, following digestion in an autoclave with the addition of potassium persulfate at a $5 \%$ final concentration (Menzel and Corwin 1965). Samples filtered through a $0.45 \mu \mathrm{m}$ filter were analyzed for chloride, fluoride, bromide, sulfate, nitrate, silicate, acetate and formate ions by a modified ion chromatography method (APHA 1992; Dionex 2002) on a Dionex DX-500 Ion
Chromatograph. Samples for total iron were digested with nitric acid and analyzed by atomic absorption spectrometry on a Perkin Elmer AA300 (APHA 1992).

Organic Carbon. Samples for dissolved organic carbon (DOC) analysis were filtered through precombusted $\left(4 \mathrm{~h}\right.$ at $\left.450^{\circ} \mathrm{C}\right)$ Whatman GF/F glass fiber filters directly into pre-combusted glass vials $\left(4 \mathrm{~h}\right.$ at $\left.550^{\circ} \mathrm{C}\right)$ that were sealed with Teflon-lined caps, and stored frozen until analysis. DOC concentrations were determined by high temperature $\left(680^{\circ} \mathrm{C}\right)$ oxidation with a Shimadzu TOC 5000 carbon analyzer. Samples for particulate organic carbon (POC) and particulate organic nitrogen (PON) were filtered on to pre-combusted Whatman GF/F filters and frozen until analysis. Prior to analysis, filters were soaked in $1.0 \mathrm{~N} \mathrm{HCl}$ and dried at $80^{\circ} \mathrm{C}$ for $24 \mathrm{~h}$. Carbon and nitrogen content was measured in a Perkin Elmer CHN Analyzer by high temperature combustion (Cotner and others 2000). 
Microbial Abundance and Processes. For the determination of bacterial abundance (BA), a 5$\mathrm{ml}$ aliquot of each water sample was preserved with $2 \%$ final concentration of $0.2 \mu \mathrm{m}$-filtered formaldehyde. Sub-samples $(0.25-1.0 \mathrm{ml})$ were acridine orange-stained, filtered onto $0.2 \mu \mathrm{m}$ black Millipore polycarbonate filters and frozen $\left(-80^{\circ} \mathrm{C}\right)$ until observation by epifluorescence microscopy (Hobbie and others 1977). Between 20 and 40 fields of view and a minimum of 300 cells were examined for every sample. Photographs were taken with a Nikon Coolsnap digital camera.

Bacterial production (BP) was estimated from rates of protein synthesis using $\left[{ }^{3} \mathrm{H}\right]$-leucine (Kirchman and others 1985; Smith and Azam 1992) supplied at saturating levels $(20 \mathrm{nM})$ to triplicate live and one killed $(5 \%$ trichloro acetic acid) of $1 \mathrm{ml}$ lake or sinkhole samples in dark incubations at in situ temperatures. Killed controls accounted for $0.5-9.0 \%$ of the radiolabel found in live samples. Rates of $\left[{ }^{3} \mathrm{H}\right]$-leucine incorporation were converted to bacterial carbon production using the standard conversion factor of $2.3 \mathrm{~kg}$ $\mathrm{C}$ produced per mole of leucine incorporated ( $\mathrm{Si}$ mon and Azam 1989). The coefficient of variance for BP measurements in individual samples ranged between $3-10 \%$. Saturation and time-course uptake curves were determined once during the research cruise.

Chemoautotrophic production (chemosynthesis) rate was estimated by tracking dark fixation of inorganic carbon (assimilation of organic carbonfree ${ }^{14} \mathrm{C}$-sodium bicarbonate) in killed controls ( $2 \%$ formaldehyde) and in triplicate live treatments against the background of a known pool of dissolved inorganic carbon (DIC; Pedros-Alio and others 1993; Wirsen and others 1993; Sorokin and others 2003). Water samples (1 ml) were incubated with $10 \mu \mathrm{Ci} \mathrm{ml} l^{-1}$ of ${ }^{14} \mathrm{C}$-sodium bicarbonate in the dark at in situ temperatures for $4 \mathrm{~h}$. Unassimilated inorganic carbon was liberated from the samples by treatment with $1 \mathrm{~N} \mathrm{HCl}$, and the radioactivity of the remaining organic carbon fraction was determined. Killed controls accounted for $1-6 \%$ of the radiolabel found in live samples. Ambient DIC concentrations were estimated from alkalinity measurements, and they ranged from $30 \mathrm{mg} \mathrm{Cl}^{-1}$ in surface waters to $48 \mathrm{mg} \mathrm{C}^{-1}$ in the sinkhole plume. Chemosynthesis rates were estimated after correcting for the radioactivity in the killed controls (Pedros-Alio and others 1993). The coefficient of variance for chemosynthesis measurements of individual samples ranged between 1 and $8 \%$.

\section{Results AND Discussion}

\section{Field Observations}

Vertical profiles of CTD and PAR revealed a water column with a mixed layer depth of $10 \mathrm{~m}$, a thermocline extending from 10 to $35 \mathrm{~m}$, a subsurface chlorophyll maximum at $30 \mathrm{~m}$, and a euphotic zone depth ( $1 \%$ of surface level PAR) of $40 \mathrm{~m}$. In the vicinity of the sinkhole, PAR levels were undetectable, temperature increased from $3.9^{\circ} \mathrm{C}$ (deep water) to $7.5^{\circ} \mathrm{C}$ (sinkhole plume) and conductivity increased from $140 \mu \mathrm{S} / \mathrm{cm}^{-1}$ (surface or deep water) to $1700 \mu \mathrm{S} / \mathrm{cm}^{-1}$ (sinkhole plume; Table 1). Normal temperatures in Lake Huron at these depths are around $4^{\circ} \mathrm{C}$.

The dimensions of the Isolated Sinkhole as mapped by side-scan sonar were approximately 40 $\mathrm{m} \times 55 \mathrm{~m}$ (Figure 2b). The depth of the deepest point in the sinkhole relative to the surrounding lake floor was approximately $2 \mathrm{~m}$. Within the larger Isolated Sinkhole region, numerous smaller depressions (0.5-3.0 m diameter) were observed. Most of these depressions showed recognizable signs of groundwater seepage as indicated by elevated conductivity and temperature measurements on the ROV's CTD. Such depressions are known as "pockmarks" in the marine literature, and are commonly reported from the Gulf of Mexico and the North Sea (Van Dover 2000).

Whereas the lake floor outside of the sinkhole was generally flat, feature-less and covered with light brown sediment (Figure 3a), the sinkhole floor was strikingly different with rolling terrain covered with conspicuous benthic mats (Figure $3 \mathrm{~b}-\mathrm{h}$ ), pockmarks (Figure $3 \mathrm{c}-\mathrm{e}$ ), and in a few locations, exposed debris apparently consisting of wood and rock (Figure 3g; see ROV video clip in Appendix 1). Two mat morphotypes were noted during the exploration. The most distinctive morphotype was an irregularlyshaped white mat (Figure 3b, d) with a definite cohesive structure that when manipulated with the M-ROVER's manipulator arm revealed a rubber-like flexible nature. The second morphotype was a brown mat that did not appear to have a cohesive structure, more so like loosely associated delicate aggregates or flocs (Figure 3b-f). Brown mats were the most common morphotype, and they were found all over the lake floor surrounding the sinkhole. Areas covered by the brownish mats sometimes had elongated sausage-shaped pink structures of unknown composition associated with them (Figure 3f). Conspicuous white and brownish mats of microbial origin are found in thermal vents and cold seeps (Van Dover 2000). 


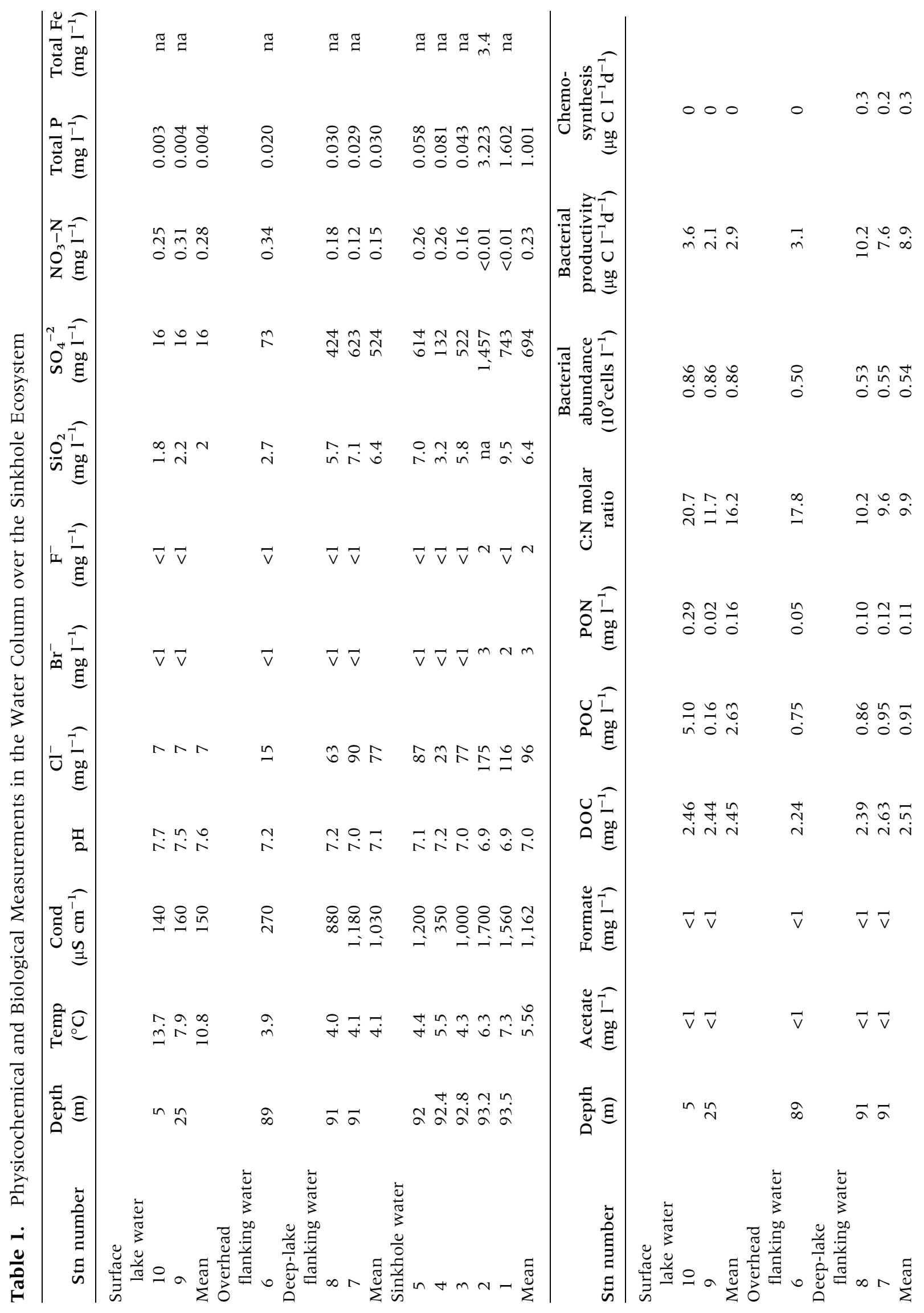




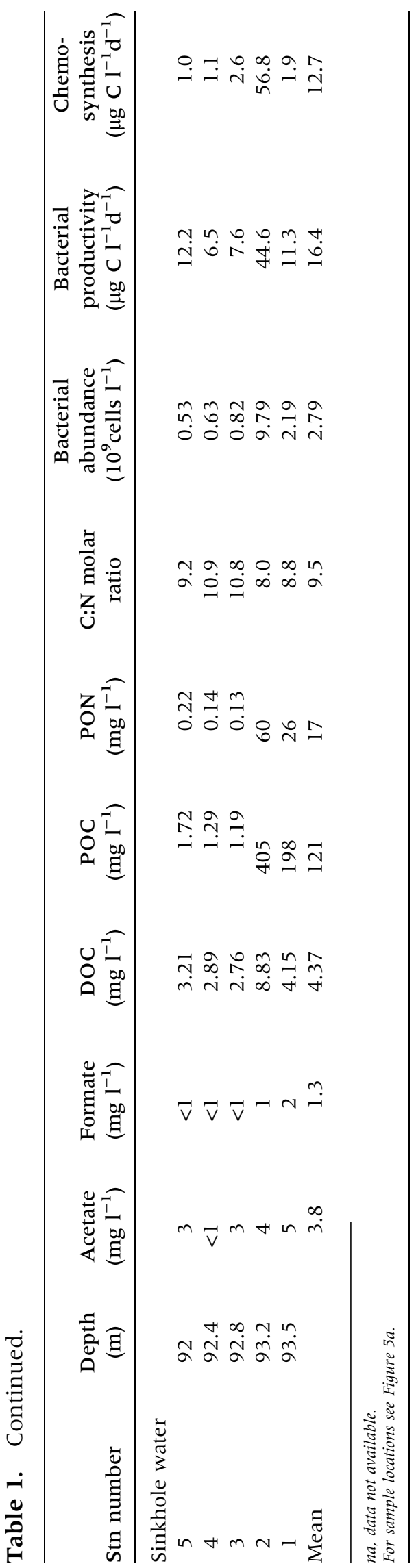

Curiously, no dense communities of metazoan invertebrates (such as the ones common in thermal vents and cold seep ecosystems; Van Dover 2000) were observed during several hours of video survey of the sinkhole environment in both 2002 and 2003. We occasionally observed live gobies and freshwater shrimp, and unidentified dead fish in the sinkhole environment.

Overlying the sinkhole environment was a patchy but distinctly visible 1-2 $\mathrm{m}$ thick cloudy layer suspended up to approximately $1 \mathrm{~m}$ above the lake floor (Figure 3c, g, h). We refer to this nebulous cloudy nepheloid-like layer as the "sinkhole plume" (see ROV video clip in Appendix 1). Higher levels of conductivity and temperature were measured within the sinkhole plume from the ROV's CTD (Figure 4), and we have included this layer in our survey and sampling of the water column over the sinkhole (Figure 5a).

In several locations, the ROV emerged below the sinkhole plume into a relatively clear area below. This layer is believed to be seeping groundwater due to its lack of turbidity (relative to the plume), elevated temperature and conductivity, and in some cases, shimmering as it "emerged" from the lake floor. In several cases during the 2002 IFE survey of this sinkhole, shimmering fluids were observed near the lake floor. Although the observed shimmering is presumably from higher dissolved solids in the seeping groundwater, we could not rule out the potential for shimmering to be caused by the ROV thrusters. The cloudiness of the sinkhole plume could be the result of chemical changes occurring in the groundwater as it mixes with the ambient lake water; however, based on data presented later in this paper, the turbidity could also result from elevated levels of microbial biomass and organic detritus that were highly variable even within the plume layer (Table 1).

Detailed CTD mapping of the horizontal plane over the sinkhole revealed patches of enhanced temperature and conductivity (Ruberg and others 2005). To better understand the relationship of conductivity and temperature with depth, we constructed a high-resolution vertical profile of conductivity and temperature in the near-bottom environment of the most prominent seep site within the sinkhole using the CTD system on the ROV (Figure 4). The survey included only about 3-4 $\mathrm{m}$ of the water column just over the lake floor where groundwater was actively seeping. However, we were unable to maneuver the ROV to survey or sample the emerging ground water di- 

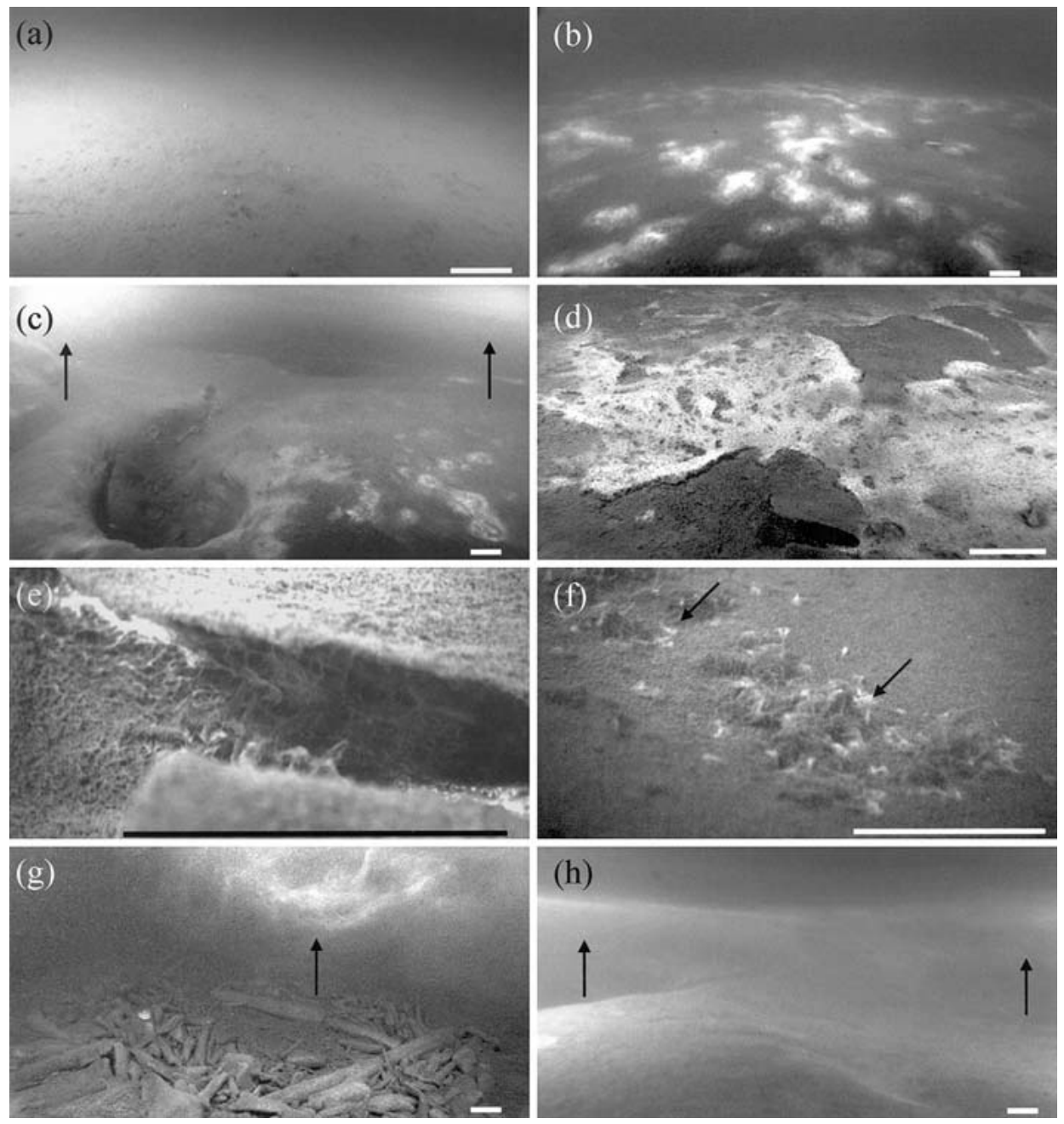

Figure 3. High-definition video still images of the Isolated Sinkhole taken by the Institute for Exploration's ROV (Little Hercules) during the 2002 expedition showing: a typical featureless lake floor away from the sinkhole, b overview of lake floor of sinkhole with brown and white mats in the sinkhole environment, c pockmark-like depression on the sinkhole lake floor adjacent to brown and white mats and a nepheloid-like cloudy layer $1-2 \mathrm{~m}$ above lake bottom (arrows), d more extensive covering of white mats adjacent to brown mats, e detail of the depression in the previous image showing brown and whitish filamentous structures, f close-up of the brownish microbial mats and pinkish sausage-shaped (arrows) inclusions, $\mathbf{g}$ wood and rock debris area with the characteristic near-bottom nepheloid-like cloudy layer (arrow) $1-2 \mathrm{~m}$ above it, and $\mathbf{h}$ side view of sinkhole with brown mats on lake floor overlain with nepheloid-like layer (arrows). Scale bar length for foreground only, is approximately $15 \mathrm{~cm}$. A brief ROV video clip showing the sinkhole lake floor and plume characteristics is given in Appendix 1.

rectly below the sinkhole plume layer without disturbing the sediment or the plume layer. Therefore, we have no CTD data for about $1 \mathrm{~m}$ of the water column immediately over the area of active groundwater seepage within the sinkhole. Both conductivity and temperature were variable but high within the nepheloid-like plume layer at around $1,000 \mu \mathrm{S} \mathrm{cm}^{-1}$ and $7^{\circ} \mathrm{C}$, respectively. Conductivity and temperature decreased sharply just above the region of the nepheloid-like plume layer ( $\sim 2-3 \mathrm{~m}$ above the lake floor), and gradually achieved background lake levels of conductivity $\left(\sim 140 \mu \mathrm{S} \mathrm{cm}^{-1}\right)$ and temperature $\left(\sim 4^{\circ} \mathrm{C}\right)$. It is unclear which factors contribute to the observed hydrodynamic stability within the plume layer. Studies by Marmorino and others (1980) have shown that high dissolved silica stabilizes warm water layers in the Lake Michigan hypolimnion.

Following the visual exploration of the sinkhole environment (Figure 3) and high resolution CTD profiling across the near bottom sinkhole plume (Figure 4), a sampling plan was developed as illustrated in Figure 5a. We sampled through the deep water sinkhole plume layer (samples 1-5), 


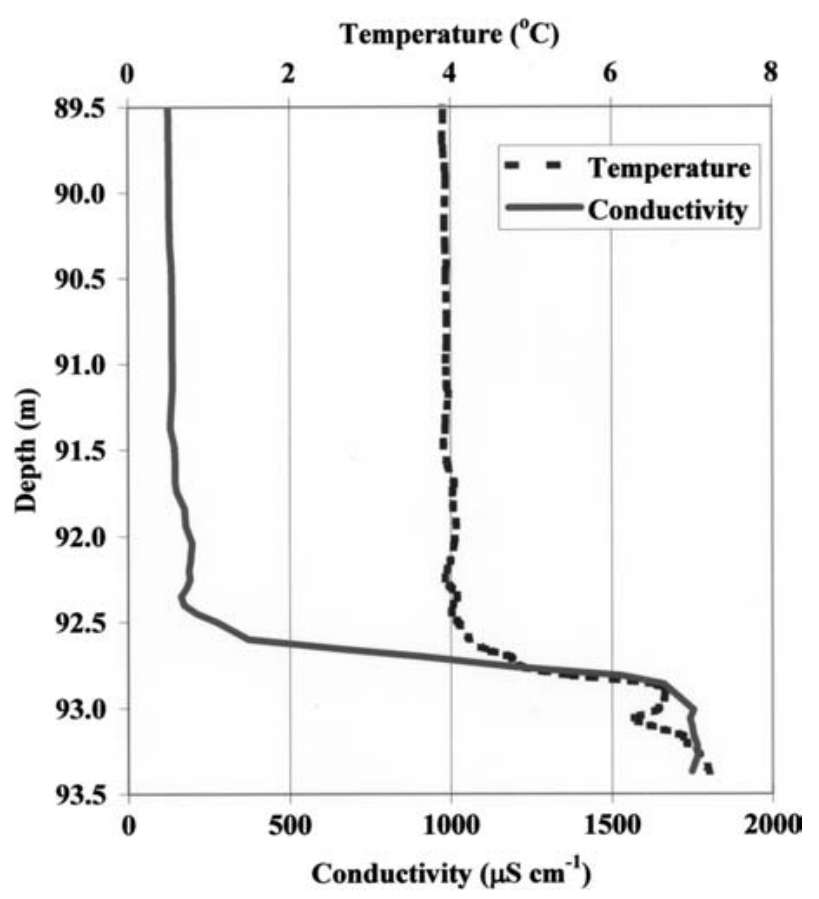

Figure 4. High-resolution vertical depth profile of conductivity and temperature in the near-bottom environment over the Isolated Sinkhole taken by the M-Rover's CTD during sampling (September, 2003).

deep-water flanking sites (samples 6-8) and surface water end members (samples 9-10). When brought to the surface, some of the samples from within the plume layer were very dark in color (Figure 5b, bottle \# 1-2) and smelled strongly of hydrogen sulfide. These sample locations did not appear as dark at depth, so the observed coloring could be an artifact of the sampling method. The deep water flanking sites-especially samples 7 and 8 were only a few meters $(<5 \mathrm{~m})$ away from the edge of the sinkhole and show some evidence of lateral diffusion of the sinkhole plume (Table 1), and therefore do not accurately reflect conditions typical of the deep waters of Lake Huron.

\section{Measurements, Inventories and Processes}

Examination of in situ measurements using ROV mounted instruments, shipboard and laboratory analyses of physicochemical conditions within the near bottom sinkhole plume layer, and comparison to lake water properties prevailing at the surface and at a comparable depth in the lake away from the sinkhole showed that the plume water was characterized by distinct properties (Table 1). Plume water was warmer than ambient lake water at $93 \mathrm{~m}$ by a few degrees $\left(3-4^{\circ} \mathrm{C}\right)$, and was characterized by 6-12 fold higher conductivity, $4-5$ fold (a)
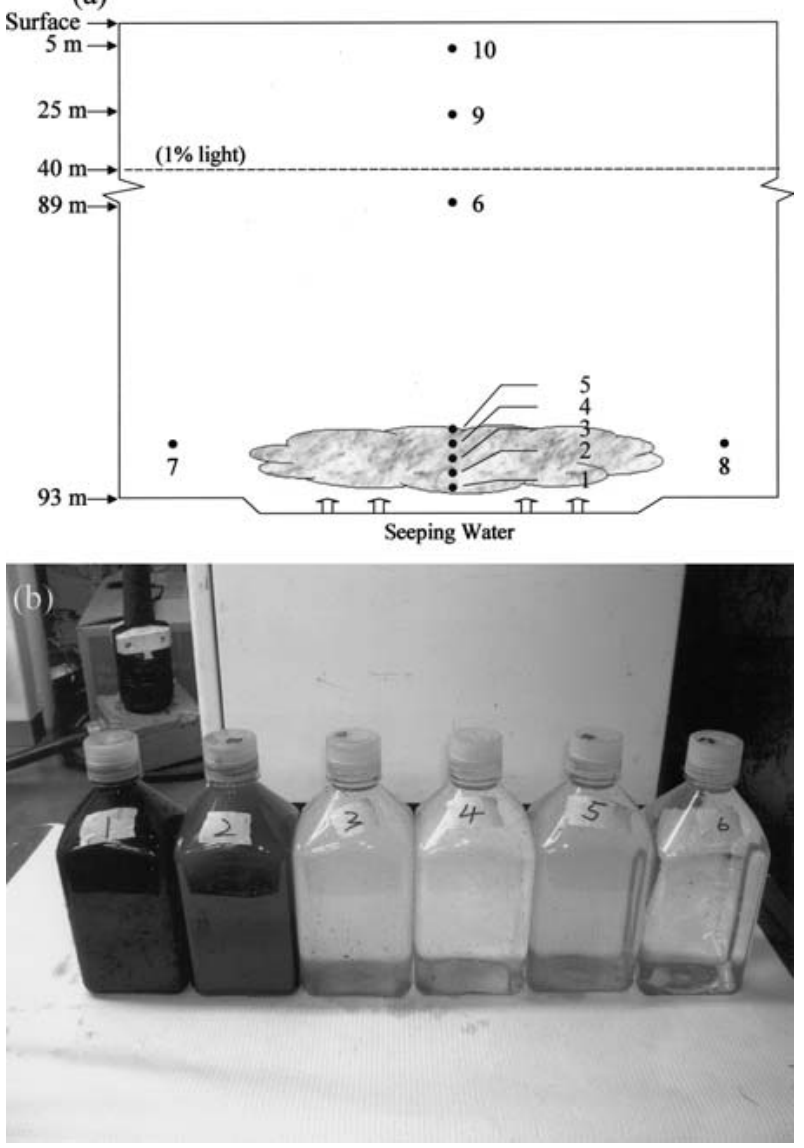

Figure 5. Generalized schematic cross-sectional diagram of the water column features and sampling sites over the Isolated Sinkhole environment (a) including the deep water nepheloid-like plume layer (near-bottom shaded area, samples 1 through 5), background deep lake water flanking samples (samples 6 through 8), background surface lake water (samples 9 and 10). Dotted line indicates depth of $1 \%$ surface sunlight (photosynthetically active radiation) penetration and a break in the water column between surface and near-bottom deep water. Photograph of recently retrieved samples collected in $1 \mathrm{l}$ polycarbonate bottles (samples 1 through 6) showing dark coloration in sinkhole plume water samples 1 and 2 (b). Bottle numbers in $\mathbf{b}$ correspond with sample numbers in a.

higher levels of silicate, 12-25 fold higher concentrations of chloride, 20-90 fold higher concentrations of sulfate, and 160-1,100 fold higher concentrations of phosphorus. The high conductivity of the sinkhole plume is mostly attributable to the high levels of chloride $\left(R^{2}=0.988, p<0.001\right)$, silicate $\left(R^{2}=0.988, p<0.001\right)$ and sulfate ( $\left.R^{2}=0.871, p<0.01\right)$. Similar concentrations of chloride, silicate, sulfate, and phosphorus have been previously measured in groundwater venting 
from shallow submerged sinkholes of the Misery Bay area in the Thunder Bay National Marine Sanctuary (up to $200 \mathrm{mg} \mathrm{l}^{-1}$ chloride, $13 \mathrm{mg} \mathrm{l}^{-1}$ silicate, $1,680 \mathrm{mg} \mathrm{l}^{-1}$ sulfate and $3 \mathrm{mg} \mathrm{l}^{-1}$ phosphate, Moreau 1983; Figure 1).

The chloride, silicate, sulfate and phosphorus composition of the water and high conductivity levels measured during this preliminary investigation of the Isolated Sinkhole (Table 1) appear to indicate that the source of the seeping groundwater is the Silurian-Devonian aquifer (Moreau 1983; Olcott 1992; Ruberg and others 2005). The detection of bromide and fluoride (up to 3 and $2 \mathrm{mg} \mathrm{l}^{-1}$, respectively) in the near bottom plume layer indicates the presence of evaporite minerals (Briggs 1970; Schereiber and Tabakh 2000) that also are characteristic of this formation.

Nitrate was the only anion that decreased in concentration in the seep water $\left(<0.01 \mathrm{mg} \mathrm{l}^{-1}\right.$ in the plume water and $0.26 \mathrm{mg} \mathrm{l}^{-1}$ outside of the plume; Table 1). Nitrate depletion in the sinkhole plume suggests the presence of a sink for nitrate in this zone. The absence of nitrate- $\mathrm{N}$ indicates that nitrate reduction could be occurring in the plume water (Jorgensen 1989). Groundwater nitrate levels in the Alpena karst region (adjacent to the sanctuary) range between $0.02-0.10 \mathrm{mg} \mathrm{l}^{-1}$, but the shallow sinkholes in Misery Bay area are relatively depleted in nitrate $\left(0.01-0.04 \mathrm{mg} \mathrm{l}^{-1}\right)$ as well as dissolved oxygen $\left(<1.5 \mathrm{mg} \mathrm{l} \mathrm{l}^{-1}\right.$; Moreau 1983)—suggesting that denitrification may be occurring at sites of groundwater seepage from submerged sinkholes. Nitrate would be first utilized as an electron acceptor under anaerobic conditions (Hordijk and others 1987). Anaerobic processes such as denitrification are known to occur in anaerobic bulk environments as well as microenvironments (Sieburth 1987). The establishment of anaerobic microenvironments may be favored by the POM-rich sinkhole plume layer where bacterial activity is high (Table 1). Although we were not able to measure oxygen levels during the 2003 exploration, a recent diver-led investigation of the Middle Island Sinkhole (Figure 1) made in situ measurements of low dissolved oxygen concentrations $(0.4-0.8 \mathrm{mg} / \mathrm{l})$ and high conductivity levels $\left(>2,000 \mu \mathrm{S} \mathrm{cm}^{-1}\right)$ in groundwater seeping at $18 \mathrm{~m}$ depth (July 2005).

The high sulfate ion concentrations in the seep water $\left(1,450 \mathrm{mg} \mathrm{l}^{-1}\right)$ can serve as electron acceptors for sulfate reducers in this environment (Kasten and Jorgensen 2000; Weber and Jørgensen 2002). Indeed, samples from the plume layer smelled strongly of hydrogen sulfide (no actual measurements were made in the present study) when brought to the surface-suggesting that anaerobic pathways of sulfate reduction and carbon transformation may be occurring in this sinkhole ecosystem (Fenchel and others 1998). The shallow seeps of the Misery Bay area sinkholes contain high levels of sulfate as well as sulfide (300-1,680 $\mathrm{mg} \mathrm{l}^{-1}$ and 25-150 $\mathrm{mg} \mathrm{l}^{-1}$, respectively; Moreau 1983).

Both phosphorus and iron may play important roles in the biogeochemistry of environments such as the sinkhole ecosystem (Fenchel and others 1998). In the present study, total phosphorus concentrations in the seep water were up to 1,100 fold higher than the ambient lake water. Total iron content was measured only in one plume sample and was found to be in high concentrations $(3.5 \mathrm{mg}$ $\mathrm{Fe} \mathrm{l}^{-1}$ ). However, at the present time, we are unable to speculate on the pathways or significance of these two elements in this ecosystem because we lack data on phosphorus and iron speciation, as well as the amount of groundwater discharge from the sinkhole.

Detection of the low molecular weight acids, acetate (up to $5 \mathrm{mg} \mathrm{l}^{-1}$ ) and formate (up to 1.5 $\mathrm{mg} \mathrm{l}^{-1}$ ) also indicates the presence of anaerobic carbon degradation (Lovley and Klug 1982; Sansone and Martens 1982; Wu and others 1997). Both formate and acetate can serve as electron donors for sulfate reducing bacteria and as electron acceptors for methanogenesis (Winfrey and Zeikus 1979; Jones and Simon 1985; Fenchel and others 1998). Anaerobic methane oxidation may be carried out by syntrophic consortia of methanotrophic archaea and sulfate-reducing bacteria (Boetius and others 2000; Orphan and others 2001). Although methane concentrations were not determined in this investigation, dissolved nutrients and concentration gradients present in the sinkhole environment appear to support a high biomass of a functionally diverse microbial community (see below)-comparable to the conditions observed over the hypersaline and anoxic Orca Basin (LaRock and others 1979).

The sinkhole plume water was characterized by fourfold higher concentrations of DOC and 400-fold higher concentrations of POC, relative to ambient lake water (Table 1). Both DOC and POC are utilized by heterotrophic bacteria to fuel the microbial food web in aquatic environments (Azam 1998; Anesio and others 2003). Molar C:N ratios of POM ranged from 21 in surface waters to 8 in the sinkhole plume (Table 1), suggesting $\mathrm{N}$ enrichment of POM within the near-bottom plume layer due to increased biological activity. The large difference in the $\mathrm{C}$ and $\mathrm{N}$ composition of POM suggests that the 


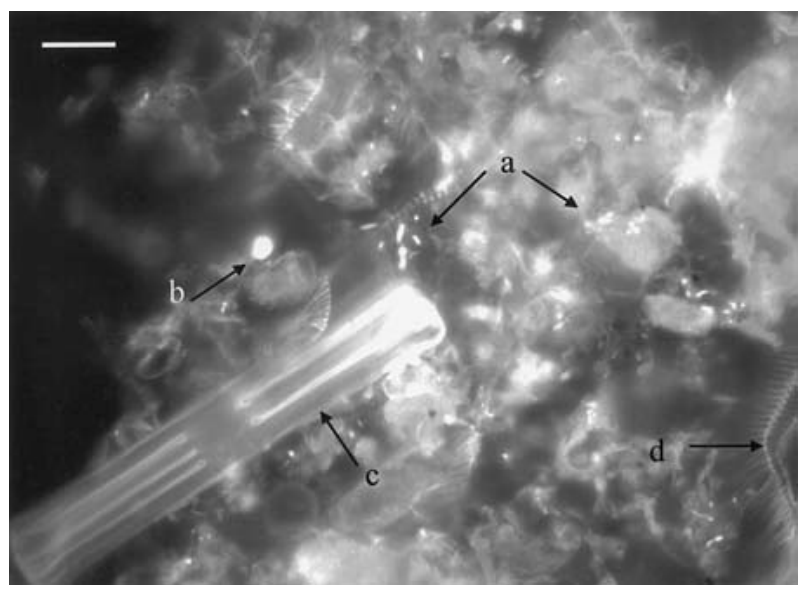

Figure 6. Epifluorescence microscope image of sample from the sinkhole plume showing numerous bacteria (a), protozoa (b), dead phytoplankton (c) and recognizable zooplankton parts (d) associated with the abundant particulate organic matter. A sample volume of $0.25 \mathrm{ml}$ was filtered onto $25 \mathrm{~mm}$ diameter $0.2 \mu \mathrm{m}$ pore size black Millipore polycarbonate filters, acridine orange stained, and viewed under blue light excitation at 1,000× magnification. Scale bar $=\sim 10 \mu \mathrm{m}$.

sinkhole ecosystem is likely generating its pool of organic matter in situ, and not just transforming surface derived detrital materials settling down from the water column.

Bacterial abundance in surface and flanking deep

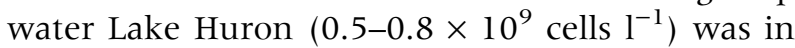
the range of values recorded for the Great Lakes and the oceans (Ducklow 2000; Biddanda and Cotner 2003). However, the abundance of bacteria in the sinkhole plume reached levels that were an order of magnitude higher than ambient lake levels

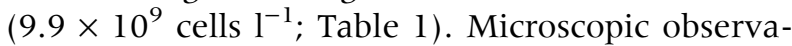
tions showed that bacteria were mostly associated with particulate matter in the sinkhole plume (Figure 6). Reddish autofluorescence of these particles emphasized their organic origins, a contention that is supported by the extremely high POC and PON concentrations (Table 1). Also, potentially bacterivorous protozoan nanoflagellates were found, suggesting that an active microbial food web was operational in this environment (Azam 1998). Indeed, chemoclines within stratified water bodies are known to harbor high densities of heterotrophic and chemosynthetic prokaryotes as well as hypoxia/anoxia tolerant phagotrophic eukaryotes that depend on prokaryotic microbes for food (LaRock and others 1979; Fenchel and others 1998).

Bacterial production in surface and flanking deep waters of Lake Huron $\left(2-10 \mu \mathrm{g} \mathrm{Cl}^{-1} \mathrm{~d}^{-1}\right)$ was in the range of values recorded for Lakes Michigan and Superior (Biddanda and Cotner 2003). However, the rates of BP within the sinkhole plume were up to an order of magnitude higher $\left(\sim 45 \mu \mathrm{g} \mathrm{C}^{-1} \mathrm{~d}^{-1}\right)$. These rates of production are near the upper range measured in oligotrophic waters (Ducklow 2000), and reflect the high concentrations of bacteria and resources for bacterial growth: DOC, POC, PON found within the sinkhole plume (Table 1). These enhanced rates of heterotrophic BP could be supported in part by the rain of phyto and zooplankton detritus and in part by in situ chemosynthesis taking place within the sinkhole plume (see below).

Prokaryotic metabolism is known to be especially suppressed at temperatures at and below to $2-4^{\circ} \mathrm{C}$ (Pomeroy and Deibel 1986)-temperatures prevailing in the deep waters of Lake Huron. However, bacterial metabolism is relieved from significant temperature suppression just above $4^{\circ} \mathrm{C}$, and lowtemperature inhibition can also be overcome by enhanced DOM availability (Pomeroy and Wiebe $2001)$ such as the warmer temperatures $\left(\sim 7^{\circ} \mathrm{C}\right)$ and approximately fourfold higher DOC concentrations found in the sinkhole plume. As temperatures increase, both growth and respiration rates increase; however, rates of respiration increase more than growth rates (Rivkin and Legendre 2001; Biddanda and Cotner 2002). Elevated metabolism (especially respiration) in the warmer waters of the sinkhole plume may thus contribute to enhanced decomposition of carbon, and consequently oxygen depletion in this system.

Dark fixation of dissolved inorganic carbon measured as an index of chemoautotrophic production showed no measurable rates in surface waters, very low rates in deep water flanking samples and significantly high rates in the sinkhole plume (Table 1). Low rates of chemosynthesis were measured in two of the three deep-water flanking samples, likely because these two sites were not adequately far away from the influence of the sinkhole plume. The rates of chemosynthesis measured in the present study were comparable to those measured in thermal vents in Yellowstone Lake (Cuhel and others 2002) and Craternaya Bay (Sorokin and others 2003).

It is notable that the measured rates of chemosynthesis of organic matter $\left(57 \mu \mathrm{g} \mathrm{C} \mathrm{l}^{-1} \mathrm{~d}^{-1}\right)$ were comparable to the measured rates of heterotrophic BP in the same water sample $\left(45 \mu \mathrm{g} \mathrm{C}^{-1} \mathrm{~d}^{-1}\right)$. This suggests that a significant portion of the carbon requirement of heterotrophic bacteria in the sinkhole plume environment could be met by concurrent chemoautotrophic production taking place on 
site. In addition to aerobic sulfide-driven chemosynthesis, chemoautotrophs may utilize other reduced species such as ammonia, sulfur and methane as electron donors under anaerobic conditions (Van Dover 2000). To better understand the relationship of our measured rates of chemosynthesis and those found in situ, further data on dissolved oxygen and reduced chemical species levels in this ecosystem are needed.

\section{Submerged Sinkhole: A Biogeochemical Hot Spot Dominated by Microorganisms}

Microorganisms are successful at colonizing and thriving in diverse habitats because they have evolved a range of metabolic capabilities that enable them to utilize energy and nutrients from a wide variety of natural resources in all known ecosystems (Schlesinger 1997; Nature, editorial 2003; DeLong 2004). In aquatic ecosystems, microorganisms play a dominant role by exerting a significant influence on all biogeochemical processes (Azam 1998; Cotner and Biddanda 2002). Identifying their abundance and diversity in any environment can allows us to picture the pathways and processes that move matter and energy within that ecosystem (Charlebois and others 2003; Gossett 2002; Teske and others 2003).

Preliminary examination of the microbial community composition of the sinkhole plume using molecular phylogenetic techniques has revealed (1) reduced species diversity amongst the Bacteria which suggests the presence of few but rapidly growing bacterial species, and (2) presence of Archea having close relationships to known sulfate-reducing and methanogenic species which suggests the submerged sinkhole ecosystem may be an extreme habitat (Marsh, Schwalbach, Fuhrman, Biddanda-Unpublished Data). Various workers have examined microbial species diversity in a variety of extreme habitats (Moyers and others 1995; Maki and others 2002), and found a decrease in microbial diversity with increasingly extreme conditions (Fenchel and others 1998).

In geothermal vents as well as cold seeps, the occurrence of reduced inorganic compounds is commonly associated with microbial chemosynthetic activity (Cuhel and others 2002), and both heterotrophic and chemosynthetic activity are found to be enhanced at physicochemical discontinuities such as oxic-anoxic boundary zones (LaRock and others 1979). The high abundance of organic matter prevailing in the sinkhole plume appears to be the result of localized but intense heterotrophic $\mathrm{BP}$ and microbial chemosynthesis. The combination of high abundance of microorganisms, inorganic nutrients, electron donors/acceptors, and organic matter may provide the context for both aerobic and anaerobic biogeochemical processes to co-occur here intensely (Sieburth 1987).

Results from the present study show that the Isolated Sinkhole environment was a hot spot of high nutrient concentrations as well as an abundant and active microbial community. In comparison to surrounding deep water, the sinkhole plume layer prevailing just over the seep was clearly characterized by higher conductivity and temperature, elevated concentrations of chloride, sulfate, phosphate, acetate, DOC, POC, PON and bacteria, as well as enhanced rates of heterotrophic BP and chemosynthesis. Such interface environments are known to be suitable for the development of both heterotrophic and chemosynthetic communities in the sea (LaRock and others 1979), and our results indicate the presence of a mixed heterotrophic-chemoautotrophic community in this freshwater ecosystem. However, the exact pathways of chemoautotrophy and the identity of the organisms that are involved in these processes in the Lake Huron sinkhole remain to be elucidated. There is clearly a need for improved sampling and in situ measurements of rate processes in the future.

Historically, exploratory research in freshwater habitats has lagged far behind that of the oceans (Wetzel 2001). Future studies should strive to expand our understanding of the structure and function of sub-ecosystems that operate within larger ecosystems such as the Great Lakes. Our future plans include continued exploration of nearshore and deeper-water sinkholes present throughout this karst system, and comparison with those found in other regions. Our hypothesis is that along a gradient of sinkholes extending from shallow to deep water, the contribution of photosynthesis and chemosynthesis to sinkhole biogeochemistry will systematically vary.

There is reason to expect similar sinkholes and seeps are present, and could be numerous, in other regions within the Great Lakes Basin where carbonate aquifer systems are present (Black 1983; Grannemann and others 2000; Figure 1). Furthermore, because there has been no systematic search for submerged sinkholes and the groundwater discharging through them, they may be more prevalent in coastal freshwater and marine environments than presumed hitherto. A challenge for the future will be to find these dynamic underwater ecosystems and comprehend the "biogeochemical tango" taking place therein. 


\section{ACKNOWLEDGEMENTS}

We acknowledge the significant contributions of Jeff Gray and the staff of the Thunder Bay National Marine Sanctuary and Underwater Preserve to the success of this preliminary investigation. We would like to thank the crew of the R/V Laurentian (NOAA and University of Michigan)-Andrew Yigiela, Glenn Tomkins, Dennis Greenwald and Dennis Donahue who made this work possible. We are thankful to Tyrone Black (Michigan Department of Environmental Quality) and Norman Grannemann (USGS) for helpful discussions on karst hydrogeology, and Russell Cuhel (Ecosystems reviewer) for significant improvements of this manuscript. Bopi Biddanda and Scott Kendall, acknowledge institutional support for this work from Alan Steinman, Director, Annis Water Resources Institute and Lake Michigan Center (Grand Valley State University). NOAA's National Marine Sanctuary Program, NOAA's Office of Ocean Exploration, and NASA's Michigan Space Grants Consortium funded this work.

\section{ApPENDIX 1}

\section{Submerged Sinkhole Ecosystem}

A brief $(\sim 1 \mathrm{~min})$ video clip acquired from the University of Michigan's remotely operated vehicle (M-ROVER) at a depth of 292-294 ft $(\sim 90 \mathrm{~m})$ showing features of the lake floor and the overlying nepheloid-like plume layer in the Isolated Sinkhole, Lake Huron, during September 2003. http:// gvsu.edu/wri/envbio/biddanda/sinkhole.htm

\section{REFERENCES}

American Academy of Microbiology. 2001. Geobiology: exploring the interface between the biosphere and the geosphere. A report from the American Academy of Microbiology. Washington DC.

APHA. 1992. Standard methods for the examination of water and wastewater. 18th edition. Washington: American Public Health Association.

Anesio AM, Abreu PC, Biddanda BA. 2003. The role of free and attached microorganisms in the decomposition of estuarine macrophyte detritus. Estuar Coast Shelf Sci 56:197-201.

Azam F. 1998. Microbial control of oceanic carbon flux. Science 280:694-6.

Beeton AM. 1984. The world's great lakes. J Great Lakes Res 10:106-13.

Biddanda BA, Benner R. 1997. Major contribution from mesopelagic plankton to heterotrophic metabolism in the upper ocean. Deep-Sea Res 44:2069-85.

Biddanda BA, Ogdahl M, Cotner JB. 2001. Dominance of bacterial metabolism in oligotrophic relative to eutrophic waters. Limnol Oceanogr 46:730-9.
Biddanda BA, Cotner JB. 2002. Love handles in aquatic ecosystems: role of dissolved organic carbon drawdown, sediment resuspension and terrigenous inputs in the carbon balance of Lake Michigan. Ecosystems 5:431-45.

Biddanda BA, Cotner JB. 2003. Enhancement of dissolved organic matter bioavailability by sunlight and its role in the carbon cycle of lakes Superior and Michigan. J Great Lakes Res 29:228-41.

Black TJ. 1983. Selected views of the tectonics, structure and karst in Northern Lower Michigan, Michigan. In: Kimmel RA, Ed. Tectonics, structure and karst in Northern Lower Michigan. Michigan Basin Geological Society Field Conference Proceedings. p 11-35.

Briggs LI Jr. 1970. Geology of gypsum in the Lower Peninsula of Michigan. In: Forum on geology of industrial minerals, sixth proceedings, Michigan Geological Society Miscellaneous Publications. p 66-77.

Boetius A, Ravenschlag K, Schubert C, Rickert D, Widdel F, Gieseke A, Amann R, Jorgensen BB, Witte U, Pfannkuche O. 2000. A marine microbial consortium apparently mediating anaerobic oxidation of methane. Nature 407:623 6.

Catacosinos RF, Harrison WB, Westjohn DB, Wollensak MS. 2001. Stratigraphic lexicon for Michigan. Michigan Department of Environmental Quality. Bulletin 8.

Charlebois RL, Beiko R, Ragan M. 2003. Branching out: microbial phylogenomics. Nature 421:217.

Coleman DF. 2002. Underwater archaeology in Thunder Bay National Marine Sanctuary, Lake Huron. Mar Technol Soc J 36:33-44.

Coleman DF. 2003. Archaeological oceanography of inundated coastal prehistoric sites. PhD Dissertation, University of Rhode Island Graduate School of Oceanography.

Cotner JB, Biddanda BA. 2002. Small players, large role: microbial influence on biogeochemical processes in pelagic aquatic ecosystems. Ecosystems 5:105-21.

Cotner JB, Johengen TH, Biddanda BA. 2000. Intense winter heterotrophic production stimulated by benthic resuspension. Limnology and Oceanogr 45:1672-6.

Crane K, Heckey B, Golubev V. 1991. Hydrothermal vents in Lake Baikal, USSR. Nature 350:281-3.

Cuhel RL, Aguilar CA, Anderson PD, Maki JS, Padock RW, Remsen CC, Klump JV, Lovalo D. 2002. Underwater domains in Yellowstone Lake: hydrothermal vent geochemistry and bacterial chemosynthesis. In: Anderson RJ, Harmon D, Eds. Yellowstone Lake: Hotbed of Chaos or Reservoir of Resilience. Yellowstone National Park: Yellowstone Center for Resources and the George Wright Society. p 27-53.

DeLong E. 2004. Microbial life breathes deep. Science 306:2198200.

Dionex. 2002. ASHC product manual. Sunnyvale (CA): Dionex Corporation, pp 41.

Ducklow H. 2000. Bacterial production and biomass in the oceans. In: Kirchman DL, Ed. Microbial ecology of the oceans. New York: Wiley-Liss. p 85-120.

Dymond J, Collier RW, Natwood ME. 1989. Bacterial mats from Crater Lake, Oregon, and their relationship to possible deeplake hydrothermal venting. Nature 342:673-5.

Fenchel T, King GM, Blackburn TH. 1998. Bacterial Biogeochemistry: the ecophysiology of mineral cycling, 2nd edn. Amsterdam: Elsevier Academic Press, p 307.

Gossett JM. 2002. Fishing for microbes. Science 298:974-5. 
Grannemann NG, Hunt RJ, Nicholas JR, Reilly TE, Winter TC. 2000. The importance of groundwater in the Great Lakes region. In: USGS water resources investigations report 00-4008. Lansing (MI): USGS.

Hobbie JI, Daley RJ, Jasper S. 1977. Use of nuclepore filters for counting bacteria by epifluorescence microscopy. Appl Environ Microbiol 22:1225-8.

Hordijk CA, Snieder M, Van Engelen JJM, Cappenberg TE. 1987. Estimation of bacterial nitrate reduction rates at in situ concentrations in freshwater sediments. Appl Environ Microbiol $53: 217-23$.

Jones JG, Simon BM. 1985. Interaction of acetogens and methanogens in anaerobic freshwater sediments. Appl Environ Microbiol 49:944-8.

Jorgensen KS. 1989. Annual pattern of denitrification and nitrate ammonification in estuarine sediment. Appl Environ Microbiol 55:1841-7.

Kasten S, Jorgensen BB. 2000. Sulfate reduction in marine sediments. In: Schulz HD, Zabel M, Eds. Marine geochemistry. Berlin Heidelberg New york: Springer. p 263-81.

Karl DM. 1999. Sea of change: biogeochemical variability in the North Pacific subtropical gyre. Ecosystems 2:181-214.

Karl DM, Wirsen CO, Jannasch HW. 1980. Deep-Sea primary production at the Galapagos hydrothermal vents. Science 207:1345-7.

Kimmel RA, Ed. 1983. Tectonics, structure, and karst in Northern Lower Michigan. In: Michigan basin geological society 1983 field conference proceedings. p 139.

Kirchman DL, K'Nees E, Hodson RE. 1985. Leucine incorporation and its potential as a measure of protein synthesis by bacteria in natural aquatic systems. Appl Environ Microbiol 49:599-607.

Klump JV, Paddock R, Anderson PA, Remsen CC, Maki J. 1988. Hydrothermal activity in Yellowstone Lake: preliminary observations of a unique lacustrine environment. EOS 69:1 109.

LaRock PA, Lauer RD, Schwarz JR, Watanabe KK, Wiesenburg DA. 1979. Microbial biomass and activity distribution in an anoxic, hypersaline basin. Appl Environ Microbiol 37:466-70.

Lovley DR, Klug M. 1982. Intermediary metabolism of organic matter in the sediments of a eutrophic lake. Appl Environ Microbiol 43:552-60.

Maki JS, Shroeder CM, Bruckner JC, Wimpee C, Neil A, Remsen CC, Aguilar C, Cuhel RL. 2002. Investigating the microbial ecology of Yellowstone Lake. In: Anderson RJ, Harmon D, Eds. Yellowstone Lake: hotbed of chaos or reservoir of resilience. Yellowstone National Park: Yellowstone Center for Resources. p 101-13.

Marmorino GO, Danos SC, Maki JS. 1980. Temperature finestructure of Lake Michigan hypolimnion. Limnol Oceanogr 25:680-99.

Menzel DW, Corwin N. 1965. The measurement of total phosphorus liberated in seawater based on the liberation of organically bound fractions by persulfate oxidation. Limnol Oceanogr 10:280-1.

Moreau RB. 1983. A review of limnological characteristics of Alpena, Michigan area flowing wells and sinkholes. In: Kimmel RA, Ed. Tectonics, structure, and karst in Northern Lower Michigan. Michigan basin geological society 1983 field conference proceedings. p 91-111.

Moyer CL, Dobbs FC, Karl DM. 1995. Phylogenetic diversity of the bacterial community from a microbial mat in an active hydrothermal cent system, Loihi seamount, Hawaii. Appl Environ Microbiol 61:1555-62.

Nature. 2003. Editorial: here, there and everywhere. Nature 425:107.

Olcott PG. 1992. Ground water atlas of the United States, Iowa, Michigan, Minnesota, Wisconsin, U.S. geological survey HA730-J, 1992.

Orphan VJ, Howes CH, Hinrichs K-U, McKeegan KD, DeLong EF. 2001. Methane-consuming archaea revealed by directly coupled isotopic and phylogenetic analysis. Science 293:484-7.

Pedros-Alio C, Garcia-Cantizano J, Calderon JI. 1993. Bacterial production in anaerobic water columns. In: Kemp PF, Sherr BF, Sherr BF, Cole JJ. Handbook of methods in aquatic microbial ecology. p 519-30.

Pomeroy LR, Deibel D. 1986. Temperature regulation of bacterial activity during the spring bloom in Newfoundland coastal waters. Science 233:359-61.

Pomeroy LR, Wiebe WJ. 2001. Temperature and substrates as interactive limiting factors for marine heterotrophic bacteria. Aqua Microb Ecol 23:187-204.

Rivkin RB, Legendre L. 2001. Biogenic carbon cycling in the upper ocean: effects of microbial respiration. Science 291:2398-400.

Reysenbach AL, Banta AB, Boone DR, Cary SC, Luther GW. 2000. Microbial essentials at hydrothermal vents. Nature 404:835.

Ruberg S, Coleman D, Johengen T, Meadows G, VanSumeren H, Land G, Biddanda B. 2005. Groundwater plume mapping in a submerged sinkhole in Lake Huron. Mar Technol Soc J 39:65-9.

Sansone FJ, Martens CS. 1982. Volatile fatty acid cycling in organic rich marine sediments. Geochem Cosmochem Acta 45:101-21.

Schelesinger WH. 1997. Biogeochemistry: an analysis of global change. London: Academic.

Schaetzl RJ, Krist F, Rindfleisch P, Liebens J, Williams T. 2000. Postglacial landscape evolution of northeastern Lower Michigan, interpreted from soils and sediments. Ann Assoc Am Geogr 90:443-66.

Schereiber BC, Tabakh M. 2000. Deposition and early alteration of evaporates. Sedimentology 47:215-38.

Sieburth JMcN. 1987. Contrary habitats for redox specific processes: methanogenesis in oxic waters and oxidation in anoxic waters. In: Sleigh MA, Ed. Microbes in the sea. New York: Wiley.

Sievert SM, Brinkhoff T, Muyzer G, Ziebis W, Kuever J. 1999. Spatial heterogeneity of bacterial populations along environmental gradient at a shallow submarine hydrothermal vent near Milos Island (Greece). Appl Environ Microbiol 65:3934842.

Simon M, Azam F. 1989. Protein content and protein synthesis rates of planktonic bacteria. Mar Ecol Prog Ser 51:201-13.

Smith DC, Azam F. 1992. A simple economical method for measuring bacterial protein synthesis rates in seawater using ${ }^{3}$ H-Leucine. Mar Microb Food Webs 6:107-14.

Sorokin YI, Sorokin PY, Zakouskina OY. 2003. Microplankton and its function in a zone of shallow hydrothermal activity: the Creternaya Bay, Kurile Islands. J Plankton Res 25:495506.

Teske A, Dhillon A, Sogin MS. 2003. Genomic markers of ancient anaerobic microbial pathways: sulfate reduction, methanogenesis, and methane oxidation. Biol Bull 204:186-91. 
Van Dover CL. 2000. The ecology of deep-sea hydrothermal vents. Princeton: Princeton University Press.

Weber A, Jorgensen BB. 2002. Bacterial sulfate reduction in hydrothermal sediments of the Guaymas Basin, Gulf of California, Mexico. Deep-Sea Res 49:827-41.

Wetzel RG. 2001. Limnology: lake and river ecosystems. London: Academic.

Wetzel RG, Likens GE. 2000. Limnological Analyses, 3rd edn. Berlin Heidelberg New York: Springer.
Winfrey MR, Zeikus JG. 1979. Anaerobic metabolism of immediate methane precursors in Lake Mendota. Appl Environ Microbiol 37:244-53.

Wirsen CO, Jannasch HW, Molyneaux SJ. 1993. Chemosynthetic microbial activity at Mid-Atlantic ridge hydrothermal vent sites. J Geophys Res 98:9693-703.

Wu HG, Green M, Scranton MI. 1997. Acetate cycling in the water column and surface sediment of Long Island Sound following a bloom. Limnol Oceanogr 42:705-13. 